\title{
Flower development, pollen viability and pollen storage test of Aeschynanthus radicans
}

\author{
FRISCA DAMAYANTI", R. VITRI GARVITA, HARY WAWANGNINGRUM, SRI RAHAYU \\ Research Center of Plant Conservation and Botanic Gardens, Indonesian Institute of Science (Bogor Botanic Gardens). \\ Jl. Ir. H. Djuanda No.13 Bogor 16122, West Java, Indonesia. Tel./fax.: +62-251-8311362, •email: friscad@ yahoo.com
}

Manuscript received: 27 January 2021. Revision accepted: 25 March 2021.

\begin{abstract}
Damayanti F, Garvita RV, Wawangningrum H, Rahayu S. 2021. Flower development, pollen viability and pollen storage test of Aeschynanthus radicans. Biodiversitas 22: 1940-1945. Aeschynanthus radicans Jack. commonly-known as lipstick flowers, is an epiphytic plant in Gesneriaceae family. It has an attractive morphology and is easy to grow. Therefore A. radicans is used as mother species for hybridization by plant breeders. The flowers of $A$. radicans are dichogamous and strongly protandrous. The pollen matures before the stigma becomes receptive and bends away and down when the stigma becomes receptive. As a thought-after material for hybridization, little is known about the flower development, pollen viability, and storability. The purpose of this study was to observe the development phase of A.radicans flowers, determine the viability of pollen during flower development, and investigate the pollen storability at $-20^{\circ} \mathrm{C}$. Flower development was observed in phases from small buds to anthesis. Pollen viability was tested in $10 \%, 15 \%$, and $20 \%$ sucrose solution for 4 hours. Pollen storage was tested at $-20^{\circ} \mathrm{C}$ for 77 days and tested for viability every three weeks. The best sucrose concentration for the germination of fresh pollen was $20 \%$. The highest pollen viability was at $\mathrm{H} 0$ was $58 \pm 3 \%$ and gradually decreased with flowerage. The lowest viability was $18 \pm 14 \%$ at flower stage H5, coinciding with the first day of stigma receptive. Pollen storage at $-20^{\circ} \mathrm{C}$ decreased pollen viability to $30,2 \pm 2 \%$ after 42 days and to $13,54 \%$ after 77 days.
\end{abstract}

Keywords: Aeschynanthus radicans, pollen, storage, sucrose, viability

\section{INTRODUCTION}

Aeschynanthus radicans Jack. are epiphytic plants belonging to the family Gesneriaceae (Missouri Botanical Garden 2018). The common name of this plant is "lipstick plant", the flowers resembling the form of lipstick. The species are widespread from Southern Thailand, Peninsular Malaysia, Singapore, Sumatra, and Borneo (Mendum 2001; Li et al. 2014; Middleton 2016). The leaves of A. radicans are thick, blade slightly fleshy, opposite, orbicular or elliptic, mostly green above and beneath, not marbled. The calyx is a tube, green with red veins, or green, puberulent, sometimes with quite long hairs (Middleton 2007). The corolla is inflated at the base and externally bright red and has the shape of a trumpet. Originally in ancient times, this plant was used by people as a traditional medicine to cure various types of diseases, such as relieving headaches and malaria (Cui et al. 2009; Budiarti et al. 2020; Nugraha et al. 2020).

According to Middleton (2016), all Aeschynanthus species are strongly protandrous, it means that male (stamens) and female (pistils) organs mature at greatly different times. The male organ matures when the flower is at anthesis, and the female organ matures several days after the male organ (Rahayu et al. 2015). This also involves the withering and side-ways movement of the stamens as the pistil elongates and the stigma enlarges (Middleton 2016). Flowers of $A$. radicans are presumed protandrous, therefore this can be a problem and failure in the process of pollination, any successful natural fruit set must rely on cross-pollination by pollinators.

A. radicans has an attractive morphology, especially the appearance of inflorescence. It is, therefore, used as an ornamental plant. They are easy to keep and fast-growing (Missouri Botanical Garden 2018). Because of its appeal to many enthusiasts, $A$. radicans began to be traded commercially. Since A. radicans have an attractive morphology and beneficial properties, they often used as material for crossing or breeding to produce new varieties (Wardani et al. 2020). According to Deswiniyanti et al. (2012), the market for ornamental plants is very interested in variations in morphology, color, fragrance, and vase life. Furthermore, according to Ulfah et al. (2015), the ornamental plant industry pays close attention to morphological variations as the main target. New variations can be generated from the hybridization or crossing process. The new plant variety is expected to have a combination of flower and leaf shapes, colors, size, and other characteristics that differ from parent plant and more attractive. On the other hand, the development of the flower and breeding system in this species is thus far unknown. Therefore, research on flower development, especially of Aeschynanthus radicans is needed. Furthermore, the study of pollen viability has been investigated in terms of its contribution to incompatibility and fertility studies or crop improvement and breeding projects (Bellusci et al. 2010).

This study was aimed to observe the flower development of $A$. radicans which includes morphological 
studies of flower development, as well as pollen viability test during and after anthesis, and pollen viability under storage at $-20^{\circ} \mathrm{C}$. Information on inflorescence phases, especially the stigma receptive period and pollen viability is very important in breeding efforts to improve flowering plant breeding programs to produce new plant varieties (Thomas and Josephrajkumar 2013; Deswiniyanti et al. 2012; Mendez and Acma 2018). Moreover, preservation of the viability and longevity of pollen is very important for plant breeding to overcome the obstacles of hybridization of species with different flowering times (Baninasab et al. 2017). An assessment of pollen viability is an imperative factor in the study of reproductive biology, hybridization and pollen storage. Nowadays, there is very limited information about pollen quality and pollen tube growth of A. radicans (Abdelgadir et al. 2012).

\section{MATERIALS AND METHODS}

\section{Materials}

The study was conducted at the Bogor Botanic Gardens and Treub Laboratory, Bogor Botanic Gardens - LIPI. The study used fresh samples of $A$. radicans flowers of plants that were planted and maintained in a greenhouse at the Bogor Botanic Gardens. We observed a minimum of 10 flowers from 10 plants from the same clonal source propagated by stem cuttings. The source was the Bogor Botanic Gardens collection, collected from Central Kalimantan (about 100 m altitude) in 2002.

\section{Methods}

\section{Flower development observation}

Observations of flower development were carried out starting from the emergence of flower buds to anthesis. The development of flower organs was carried out from flower blooms (anthesis) to fifth day after full bloom. Every stage is observed, defaced, and documented. The morphological parameters measured were the length of the peduncle, petals, corolla, pistil, short stamens, and long stamens. Measurement of morphological parameters was carried out on the first day of anthesis (H0), first day after full bloom (H1), then every further until the maximum growth was achieved in this case at the fifth day after full bloom (H5).

\section{Pollen viability test}

The pollen to be tested was taken from fresh flowers at various stages of flower development (H0-H5). The flowers were picked from greenhouse-grown plants and transferred to the microscope room at the Treub Laboratory and the pollen immediately transferred to the sucrose solution. Before the pollen was taken, the morphological parameters of the flowers were observed and documented. Then, the flower corolla was cut a few centimeters to simplify the separation of pollen from the stamens. Thereafter, the pollen was sampled using tweezers and placed into a petri dish. In this study, we used sucrose media with various concentrations, i.e., $10 \%, 15 \%, 20 \%$. The pollen which had been separated from the stamens, was divided into three Petri dishes then each of them was filled with $10 \%, 15 \%, 20 \%$ sucrose solution until the pollen was submerged. Each treatment was applied for 4 hours. After this time, the pollen was taken with pipet as much as one drop from the petri dish and placed on top of the microscope slides. Viability of the pollen was observed as percentage germination pollen.

Pollen germination was observed under a microscope with an objective of 100x magnification. The microscope was equipped with Optica Vision Lite 2.1 software, Italia. Pollen was counted as germinated when the length of the tube was equal to or longer than diameter of the pollen (Abdelgadir et al. 2012; Sari et al. 2013). The percentage of pollen viability is calculated using the following formula:

$$
\text { Viability }=\frac{\text { The number of pollen germinating }}{\text { Total pollen in the field of view }} \times 100
$$

\section{Pollen viability with storage treatment}

Pollen of the flower development phase with the highest viability was used for storage tests. Pollen of this flowering phase was taken and stored in tube $1.5 \mathrm{ml}$. Pollen was stored at $-20^{\circ} \mathrm{C}$ for approximately 77 days. Viability of pollen as pollen germination was tested every 3 weeks as described above on a stored pollen subsample.

\section{RESULTS AND DISCUSSION}

\section{Flower development}

In this study, we observed the flower development of $A$. radicans including the process of developing $A$. radicans flowers from initiation to anthesis (Figure 1), development of pistils and stamens during and after anthesis flowers (Figure 2), development of various parts or organs of the $A$. radians flower after anthesis (Figure 3 ), and morphology of A. radicans flowers $\mathrm{H} 0$ to $\mathrm{H} 5$ (Figure 4).

\section{Pollen viability}

Pollen germination and viability of $A$. radicans pollen with various kinds of sucrose media concentration is showed in Figure 5-6.

\section{Discussion}

In this study, we observed the flower development of $A$. radicans from small bud to anthesis with special focus on the pistil and stamens and pollen viability from anthesis (H0) to five days after anthesis (H5). The development of A. radicans flowers becomes visible to the naked eye with the appearance of solitary light green buds of $1 \mathrm{~mm}$ size at the ends, and in leaf axils (Figure 1). The calyx has five sepals fused to a tube. Early development of the ovalshaped flower buds sees an enlargement from about 2-5 $\mathrm{mm}$ (Figure 1.A) to $1.5 \mathrm{~cm}$ within 10-12 days (Figure 1.B). After an additional 5 days, the calyx bud opened slightly and the red flower bud appears (Figure 1.C). The corolla was still in bud stage after several days (Figure 1.D). About one week later, the flower elongated to $1.8-2 \mathrm{~cm}$. At this time, the tip of the bud began to swell slightly (Figure 1.E). The flower began to open slightly after reaching the maximum length, indicating that the $A$. radicans flower is 
ready for anthesis (Figure 1.F). One to two days later, the flower was fully in anthesis (Figure 1.G). The flowers are strongly protandrous and at this stage, the anthers are mature and shed pollen, while the female organs, i.e. pistil and stigma, are immature (Middleton 2016). After anthesis, the pistil continued to elongate over 5 days (Figure 1.H). In general, A. radicans had hairy peduncles, petals and corollas. The sepal tubes remained light green from the beginning of flower development until flower abscission. This is in contrast to A. radicans var. 'Mona Lisa' where the young buds gradually turn dark red (Ulfah et al. 2015).

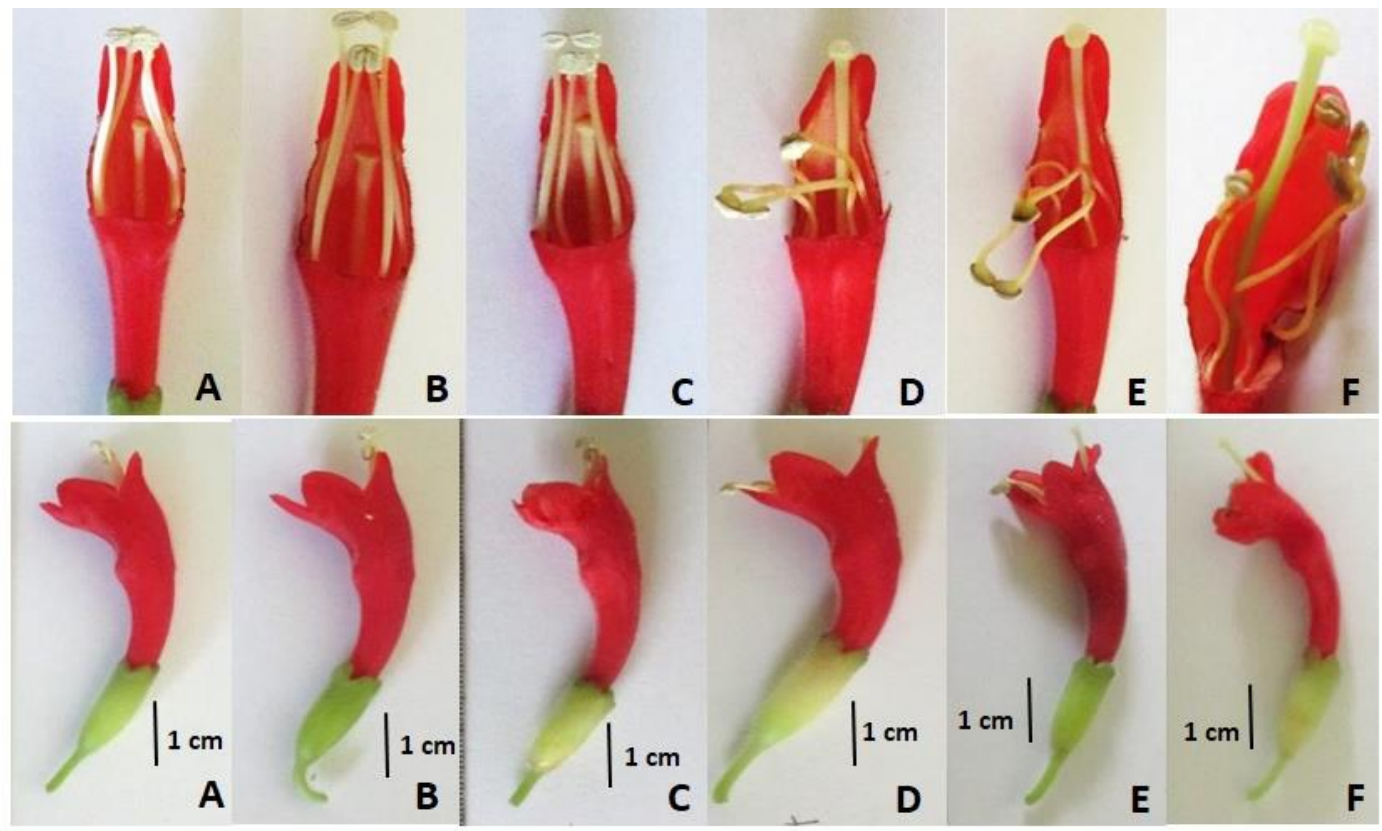

Figure 2. Development of pistil and stamens. A. H0, B. H1, C. H2, D. H3, E. H4, F. H5.

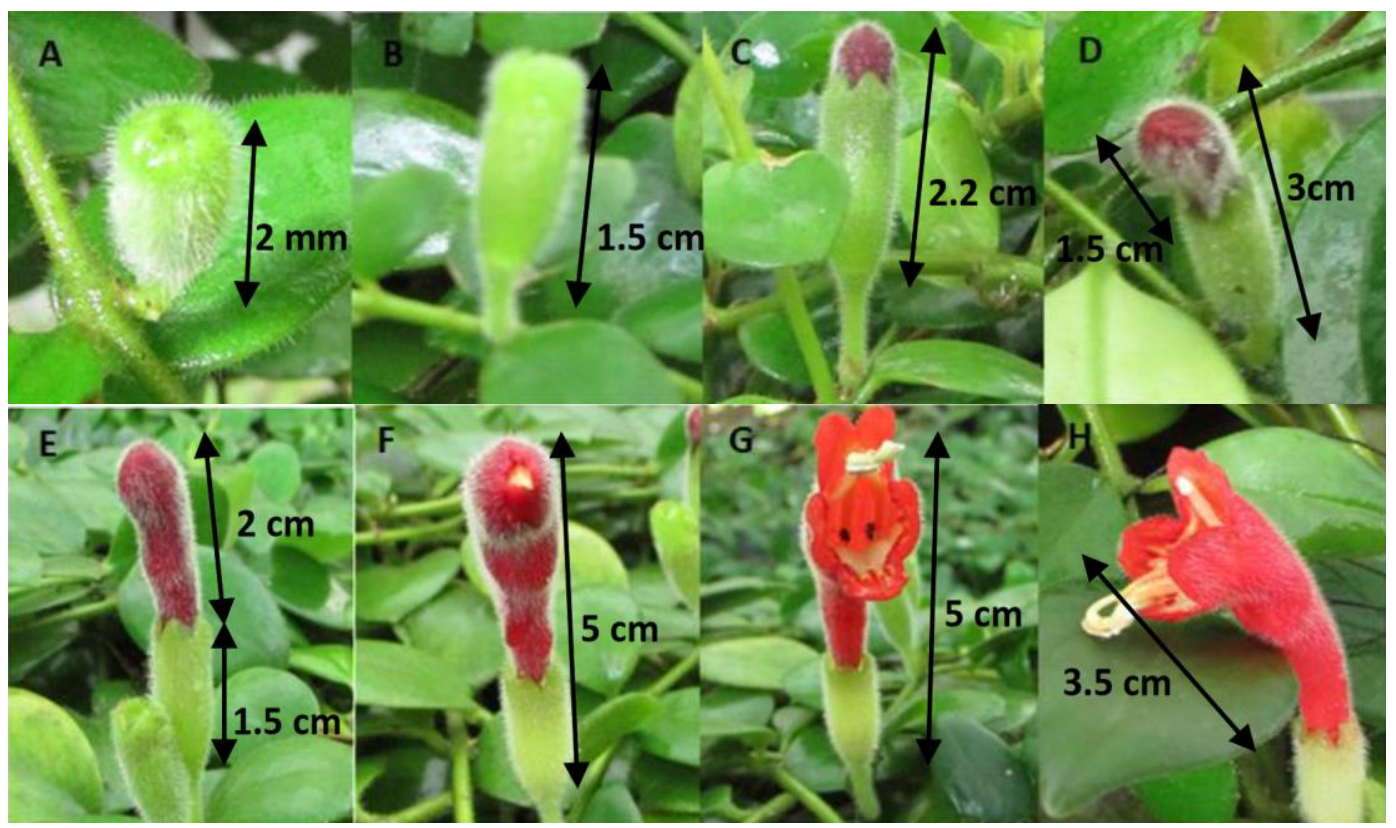

2

Figure 1. Stages in developing flower of A. radicans from small buds to anthesis. (A) $2 \mathrm{~mm}$ flower bud, (B) Elongation of flower buds to $1,5 \mathrm{~cm},(\mathrm{C})$ Corolla appears as redbud from the calyx tube, (D) Corolla tube increases in length to 1,5 cm, (E) Corolla bud reaches maximum length of $2 \mathrm{~cm}$, the tip of the bud began to swell slightly, (F) Corolla bud starts to open, $(\mathrm{G})$ Anthesis (corolla fully open), (H) H4 stage of flower development 


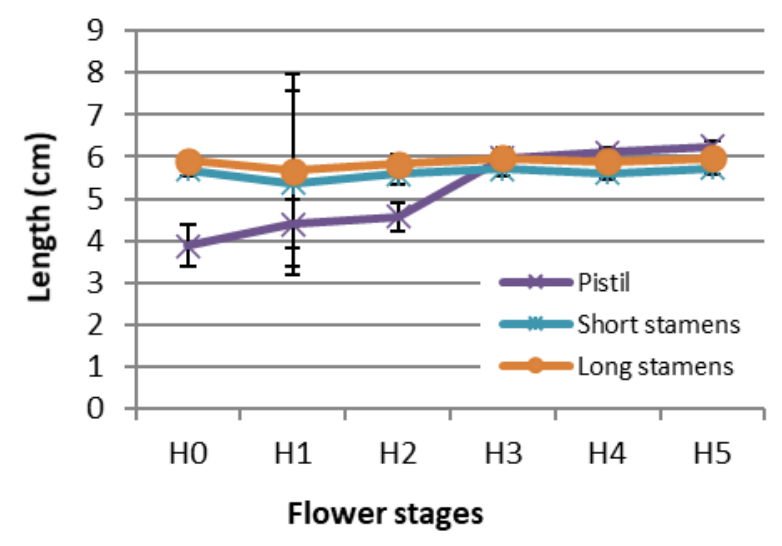

Figure 3. Development of various parts of the A. radians flower after anthesis

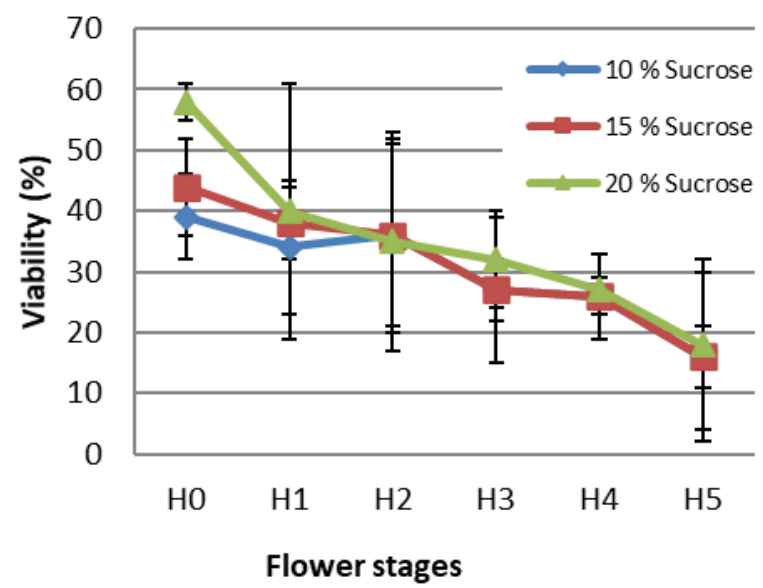

Figure 5. Viability of $A$. radicans pollen in sucrose at various concentration

To see the development of male and female organs in detail part of the corolla was cut away (Figure 2). The four stamens, arranged in two pairs, were in $A$. radicans attached $5 \mathrm{~cm}$ from the base to the inside of the corolla tube and occupied the upper half of flowers (Figure 2A) (Middelton 2016). At the time of anthesis (H0), the length of the pistil was $3.9 \mathrm{~cm}$, much shorter than the corolla which was $5 \mathrm{~cm}$ at this point in time (Figure 2A). The pistil elongated as the flower aged after anthesis. Its length did not exceed the corolla until the third day after anthesis (H3) (Figures 2D and 3). Between the second and third day, the growth of the pistil experienced a significant increase and exceeded the corolla. Generally, female maturity is marked by the receptivity of the stigma that is covered by secreted exudates containing sugar and other substances (Ulfah et al. 2015). However, in the $A$. radicans the mature stigma does not produce exudates, and determination of the stigma receptivity was based on its size when it reached its maximum diameter of $0.5 \mathrm{~cm}$ at stage $\mathrm{H} 5$ (Figure 2F). The

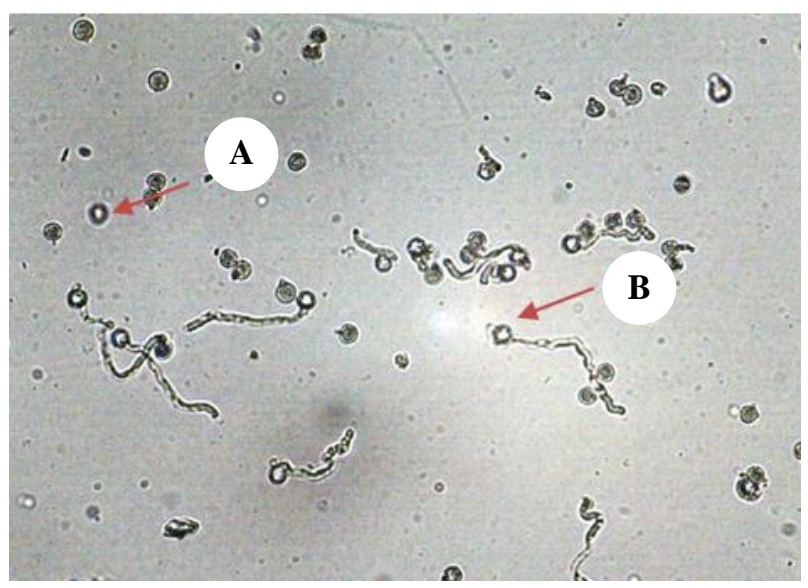

Figure 4. Pollen germination (A) Indicates ungerminated pollen; (B) Indicates germinated pollen

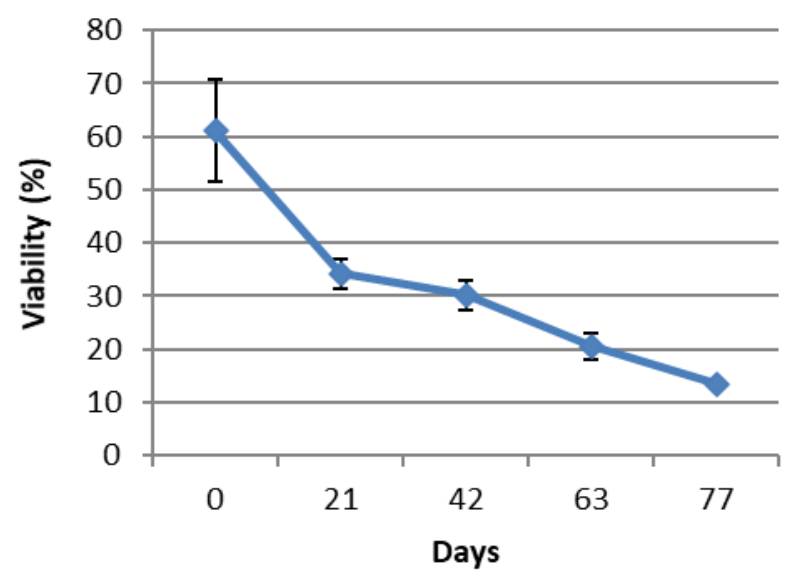

Figure 6. Pollen viability of $A$. radicans (HO) under the storage at $-20^{\circ} \mathrm{C}$

mature stigma will occupy the space where the mature stamens were placed at stages $\mathrm{H} 1$ and $\mathrm{H} 2$.

Aeschynanthus radicans has four stamens arranged in two pairs with the anthers of each pair fused at their tips, with two long and two short filaments (Figure 2). The length of the two stamen pairs at anthesis is parallel to the corolla. The growth of the stamens lengthens is relatively the same during anthesis to $\mathrm{H} 3$. In this stage, the stamen started to droop and curve downwards (H3), and later backward (H4), then became brownish in color in stages H4 and H5 (Figure 2). This condition correlated with the quality of $A$. radicans pollen which was best at $\mathrm{HO}$ and decreased with increasing age of the flowers (Figure 5). This maturation pattern was inverse to the female flower organ, where the stigma matured with increasing flowerage. This flower development pattern prevents selfpollination and promotes cross-pollination. Self-pollination plants need pollen from their own flowers, while cross- 
pollinated plants require pollen from other flowers (Rahayu et al. 2015).

The temporal difference in the maturity of male and female organs is termed dichogamy (Cardoso et al. 2018). In addition to its dichogamy, $A$. radicans has a different length of pistil and stamen in a flower. In this case, when the pistil is mature, the pistil is longer than the stamens and the stamens have bent away from the stigma (Figures 2), thus self-pollination is prevented because pollen cannot reach the stigma. Therefore, pollination of this plant requires the help of sunbird (Chen et al. 2019).

This study also carried out measurements of the length of other parts of the A. radicans flower organ. The results obtained by organ parts such as pedicel length, calyx, and corolla showed a stable size throughout $\mathrm{H} 0$ to $\mathrm{H} 5$; the pedicels are $1 \mathrm{~cm}$ long, the calyx around $1.8-1.9 \mathrm{~cm}$ and the corolla around $5-5.1 \mathrm{~cm}$. These results are in accordance with Middleton (2016).

In this study, we used a sucrose medium with various concentrations, i.e. $10 \%, 15 \%$, and $20 \%$ to test the viability of pollen at and after anthesis. The different sucrose concentrations were used to determine the concentration that produced the highest germination rate in A. radicans pollen. Sucrose is contained in the medium as energy source needed for pollen to germinate (Patel and Mankad 2015). Pollen that produces a minimum pollen tube length matching its diameter was regarded as germinated, and germinated pollen was regarded as viable pollen (Abdelgadir et al. 2012; Sari et al. 2013) (Figure 4). Pollen with poor tube growth is likely to be ineffective in fertilization (Solusoglu and Cavusoglu 2014).

The results obtained from this study showed that at flower stage $\mathrm{H} 0$ pollen viability in $10 \%$ sucrose was $39 \pm 7 \%$, in $15 \%$ sucrose was $44 \pm 8 \%$, and in $20 \%$ sucrose was $58 \% \pm 3 \%$ (Figure 5). Over flower stages, H1 to H5 the viability of pollen steadily decreased. In $\mathrm{H} 5$ pollen, the viability of pollen was $16 \pm 5 \%$ in $10 \%$ sucrose, $16 \% \pm 14 \%$ in $15 \%$ sucrose, and $18 \% \pm 14 \%$ in $20 \%$ sucrose (Figure 5). The results indicated that the highest viability of pollen $A$. radicans occurred at the beginning of anthesis $(\mathrm{H} 0)$ in all treatments sucrose concentration $(10 \%, 15 \%, 20 \%)$. The steady viability decrease over time after anthesis is biologically logical, and has been observed in other plants, such as Cannabis sativa and Lilium. (Choudhary et al. 2014; He et al. 2017). According to Hersuroso et al. (1984), the pollen viability should be above $30 \%$. In this study, it is not recommended to use pollen after the third day after anthesis because of the low germination rate in coconut. Of the three sucrose concentrations, $20 \%$ showed the best results with viability of $58 \pm 3 \%$ at $\mathrm{H} 0$ compared to $10 \%$ and $15 \%$ sucrose concentration (Figure 5). These results were in line with research conducted by Baloch et al. (2001) where $20 \%$ sucrose concentration produced most germinated pollen in Hibiscus esculentus. On the other hand, based on results of research by Gandadikusumah et al. (2017) on pollen germination of Aeschynanthus tricolor in vitro culture used $10 \%$ sucrose. Overall, therefore, based on our empirical results for A. radicans, we used $20 \%$ sucrose concentration for pollen storage experiments.
According to Mondal and Ghanta (2012), pollen storage is generally used for plant breeding purposes and to extend the time period for viable pollen to be available. The pollen viability in all peony cultivars was confirmed by the in vitro pollen germination test and $\mathrm{I}_{2}-\mathrm{KI}$ staining method, pollen was stored for more than one year under $4^{\circ} \mathrm{C},-4^{\circ} \mathrm{C}$, $20^{\circ} \mathrm{C}$, and $-76^{\circ} \mathrm{C}$. The best result of pollen stored at $-76^{\circ} \mathrm{C}$ showed a significantly slower rate of viability reduction (Du et al. 2018). The results of research by Gandadikusumah et al. (2017) suggested that pollen of first anthesis day (H0) flowers of A. tricolor could be stored at $20^{\circ} \mathrm{C}$ for up to 127 days. Furthermore, the viability of some types of pollen from other species stored at $0^{\circ} \mathrm{C}$ or $-15^{\circ} \mathrm{C}$, can be extended up to 3 years if the relative humidity of pollen is maintained between $10 \%$ and $50 \%$ (Gandadikusumah et al. 2017). Williams and Brown (2018) hypothesized that pollen cell number (bicellular or tricellular) and pollen water content (hydrated or dehydrated) are positively correlated effects on pollen performance, tricellular pollen had a $30 \%$ higher hydration index than bicellular pollen.

The results of the storage experiment showed that the viability of $A$. radicans pollen stored at $-20^{\circ} \mathrm{C}$ decreased with the length of storage (Figure 6). The pollen viability at stage $\mathrm{H} 0$ was highest at $61.1 \pm 9 \%$ and after storage at $20^{\circ} \mathrm{C}$ for 21 days $(\mathrm{H} 21)$ the viability decrease to almost by half to $34.2 \pm 2 \%$, and only slightly to $30.2 \pm 2 \%$ after storage for 42 days (H42). From $\mathrm{H} 21$ to $\mathrm{H} 77$ the pollen viability declined almost linearly to $13.5 \%$. The total decrease in pollen viability from $\mathrm{H} 0$ to $\mathrm{H} 77$ was $47.5 \%$. Given the artificial threshold of $30 \%$ of Hersuroso et al. (1984), one could conclude that $A$ radicans pollen of stage $\mathrm{H} 0$ could be successfully stored for 42 days. This was not the same for A. tricolor, where pollen viability remained viable at $-20^{\circ} \mathrm{C}$ remained above $30 \%$ until H112, almost 4 months (Gandadikusumah et al. 2017). However, the two studies are not readily comparable, since the pollen viability of $A$. tricolor before storage on the first day (H0) was $96.3 \%$ (Gandadikusumah et al. 2017), while for A radicans it was only $61.1 \pm 9 \%$. The difference in initial pollen viability between the species is likely not species-specific, but more likely due to the microclimatic conditions during flower development. We can compare the pollen viability of $A$. radicans and $A$ tricolor since both were collected from the same habitat in Central Kalimantan and grew alongside the same growing conditions at the greenhouse of the Bogor Botanic Gardens. However, the time of pollen harvest was different, and A. tricolor pollen was harvested in January, i.e. in the wet season, while the pollen of A. radicans was harvested in April i.e in dry conditions. The microclimate in the greenhouse was different in the wet and dry seasons. In the April dry conditions, pollen formation of $A$. radicans may have proceeded under water stress, which is known to reduce the viability of pollen (Razzaq et al. 2019). Moreover, according to Mendez and Acma (2018), the viability of pollen is also affected by relative atmospheric humidity at shedding and pollen transport and pollen of different species. They need a high level of relative humidity to germinate. 
In conclusion, the flower of Aeschynanthus radicans was found to be strongly protandrous. Shortly after anthesis, the stamens bend away and pistil elongates and the stigma becomes receptive. The duration of flower development was between 30-35 days starting from $1 \mathrm{~mm}$ small bud to anthesis under the conditions in the glasshouse at Bogor Botanic Gardens. In this study, the highest pollen viability was found at stage $\mathrm{H} 0$ with $20 \%$ sucrose concentration around $58 \% \pm 3 \%$ and tended to decrease gradually with flower age. It was lowest at stage H5 with $18 \% \pm 14 \%$, coinciding with the first day of stigma receptive. At $-20^{\circ} \mathrm{C}$ pollen viability remained above $30,2 \pm 2 \%$ until 42 days but is only $13.5 \%$ after 77 days of cold storage. Our study indicates that $A$. radicans pollen can be efficiently stored at $-20^{\circ} \mathrm{C}$ for up to 42 days.

\section{ACKNOWLEDGEMENTS}

The author would like to thank the Research Center of Plant Conservation and Botanic Gardens, Indonesian Institute of Science, Bogor, Indonesia for providing the samples and research facilities. We also would like to thank the head of the Treub Laboratory of Bogor Botanic Gardens, Indonesia, to allow microscopic facilities. Fredy Patiruhu thanked to his assist in maintaining the Aeschynanthus radicans collection as research materials.

\section{REFERENCES}

Abdelgadir HA, Johnson SD, Van Staden J. 2012. Pollen viability, pollen germination and pollen tube growth in the biofuel seed crop Jatropha curcas (Euphorbiaceae). South Afr J Bot 79: 132-139. DOI: 10.1016/j.sajb.2011.10.005.

Baloch MJ, Lakho AR, Bhutto H, Solangi MY. 2001. Impact of sucrose concentrations on in vitro pollen germination of okra, Hibiscus esculentus. Pak J Biol Sci 4 (5): 402-403. DOI: 10.3923/pjbs.2001.402.403.

Baninasab B, Tabori M, Yu J, Zhang Y, Wang X, Deschiffart I, Khanizadeh S. 2017. Low-temperature storage and in vitro pollen germination of selected spring wheat accessions. J Agric Sci 9 (9): 16.

Bellusci F, Musacchio A, Stabile R, Pellegrino G. 2010. Differences in pollen viability in relation to different deceptive pollination strategies in Mediterranean orchids. Ann Bot 106 (5): 769-774. DOI: 10.1093/aob/mcq164.

Budiarti M, Mazury A, Mujahid R, Sari AN, Jokopriyambodo W, Widayat T, Wahyono S. 2020. The use of antimalarial plants as traditional treatment in Papua Island, Indonesia. Heliyon 6 (12): e05562. DOI: 10.1016/j.heliyon.2020.e05562.

Cardoso JCF, Viana ML, Matias R, Furtado MT, de Souza Caetano AP, Consolaro H, de Brito VLG. 2018. Towards a unified terminology for angiosperm reproductive systems. Acta Bot Bras 32 (3): 329-348. DOI: 10.1590/0102-33062018abb0124.

Chen KH, Lu JY, Wang CN. 2019. Effective pollination of Aeschynanthus acuminatus (Gesneriaceae) by generalist passerines, in sunbird-absen East Asia. Nat Sci Rep 9: 17552. DOI: 10.1038/s41598-019-53035-2.

Choudhary N, Siddiqui MB, Bi S, Khatoon S. 2014. Effect of seasonality and time after anthesis on the viability and longevity of Cannabis sativa pollen. Palynology 38 (2): 235-241. DOI: 10.1080/01916122.1014.892906.

Cui J, Chen J, Henny RJ. 2009. Regeneration of Aeschynanthus radicans via direct somatic embryogenesis and analysis of regenerates with flow cytometry. In Vitro Cell Dev Biol Plant 45 (1): 34-43. DOI: 10.1007/s11627-008-9147-9.

Deswiniyanti NW, Astarini IA, Puspawati NM. 2012. Studi fenologi perbungaan Lilium longiflorum Thunb. (Flowering phenology study of Lilium longiflorum Thunb.). Metamorfosa I (1): 6-10. [Indonesian]

Du G, Xu J, Gao C, Lu J, Li Q, Du J, Lu M, Sun X. 2018. Effect of low storage temperature on pollen viability of fifteen herbaceous peonies. Biotechnol Rep 21, e00309. DOI: 10.1016/j.btre.2019.e00309.

Gandadikusumah VG, Wawangningrum H, Rahayu S. 2017. Pollen viability of Aeschynanthus tricolor Hook. J Trop Life Sci 7 (1): 5360. DOI: 10.11594/jtls.07.01.09.

He G, Hu F, Ming J, Liu C, Yuan S. 2017. Pollen viability and stigma receptivity in Lilium during anthesis. Euphytica 213 (10): 1-10. DOI: 10.1007/s10681-017-2019-9.

Hersuroso I, Suharyo, Hastjarjo S, Faswani Y. 1984. Panduan Kebun Induk Kelapa Hibrida. Pusat Penelitian Kelapa. [Indonesian]

Li Q, Deng M, Xiong Y, Coombes A, Zhao W. 2014. Morphological and photosynthetic response to high and low irradiance of Aeschynanthus longicaulis. Sci World J. DOI: 10.1155/2014/347461.

Mendez NP, Acma FM. 2018. In vitro studies on pollen viability, pollen germination and pollen tube growth of Hornstedtia conoidea Ridl. - a Philippine endemic ginger species. J Trop Life Sci 8 (3): 303-310. DOI: $10.11594 /$ jtls.08.03.13.

Mendum M, Lassing P, Weber A, Christie F. 2001. Testa and seed appendage morphology in Aeschynanthus (Gesneriaceae): Phytogeographical pattern and taxonomic implications. Bot J Linn Soc 135 (3): 195-213. DOI: 10.1111/j.1095-8339.2001.tb01091.x.

Middleton DJ. 2007. A Revision of Aeschynanthus (Gesneriaceae) in Thailand. Edinb J Bot 64 (3): 363-429. DOI: 10.1017/S0960428607004878.

Middleton DJ. 2016. A revision of Aeschynanthus (Gesneriaceae) in Singapore and Peninsular Malaysia. Gard Bull Sing 68 (1): 1-63. DOI: $10.3850 / \mathrm{S} 2382581216000016$.

Missouri Botanical Garden. 2018. Aeschynanthus radicans. http://www.missouribotanicalgarden.org/PlantFinder/PlantFinderDeta ils.aspx?kempercode $=\mathrm{b} 542$.

Mondal S, Ghanta R. 2012. Studies on in vitro pollen germination of Lawsonia inermis Linn. Adv Biores 3 (3): 63-66.

Nugraha AS, Triatmoko B, Wangchuk P, Keller PA. 2020. Vascular epiphytic medicinal plants as sources of therapeutic agents: Their ethnopharmacological uses, chemical composition, and biological activities. Biomolecules 10 (2): 181. DOI: 10.3390/biom10020181.

Thomas RJ, Josephrajkumar A. 2013. Flowering and pollination biology in coconut. J Plantation Crops 41 (2): 109-117.

Patel E, Mankad A. 2015. Sucrose needs for pollen germination of Impatiens balsamina L. Intl J Innovative Res Sci Eng Tech 4 (10): 10242-10244. DOI: 10.15680/IJIRSET.2015.0410104.

Rahayu S, Wawangningrum H, Garvita RV. 2015. Morphological characteristic and flower development of Aeschynanthus tricolor Hook. (Gesneriaceae). Berita Biologi 14 (3): 203-211. DOI: 10.14203/beritabiologi.v14i3.1822. [Indonesian]

Razzaq MK, Rauf S, Khurshid M, Iqbal S, Bhat JA, Farzand A, Riaz A, Xing G, Gai J. 2019. Pollen viability an index of abiotic stresses tolerance and methods for the improved pollen viability. Pak J Agric Res 32 (4): 609-624. DOI: 10.17582/journal.pjar/2019/32.4.609.624.

Sari NLGCT, Kriswiyanti E, Darsini NN. 2013. The development of microgametophyte and pollen viability of coconut ancak (Cocos nucifera L. 'Ancak'). Jurnal Simbiosis 1 (2): 51-58. [Indonesian]

Solusoglu M, Cavusoglu A. 2014. In vitro pollen viability and pollen germination in cherry laurel (Prunus laurocerasus L.). Sci World J. DOI: $10.1155 / 2014 / 657123$.

Ulfah SM, Dorly, Rahayu S. 2015. Flower development and pollen viability of Aeschynanthus radicans var. 'Monalisa' at Bogor Botanic Gardens. Bulletin Kebun Raya 19 (1): 21-32. [Indonesian]

Wardani FF, Damayanti F, Rahayu S. 2020. Respon pertumbuhan dan pembungaan bunga lipstik 'Soedjana Kasan' terhadap aplikasi GA, Etefon, dan Paklobutrazol. J Agron Indonesia 48 (1): 75-82. DOI: 10.24831/jai.v48i1.29141. [Indonesian]

Williams JH, Brown CD. 2018. Pollen has higher water content when dispersed in a tricellular state than in a bicellular state. Acta Bot Bras 32 (3): 454-461. DOI: 10.1590/0102-33062018abb0129. 